\title{
Self-Imprints of Nature
}

\section{An "Unpacked Event"}

At what was billed as an "Unpacked Event" on February 20, 2019, a well-known South Korean electronics group presented its latest generation of smartphone models. ${ }^{1}$ Interest centered especially on a mobile phone called Fold that opens up like a book. At the event, images of the device were officially revealed to the world (although they had previously been circulating) that showed, on each half of the display, a pair of butterfly wings in intense colors (orange, green, and blue), with the area of transition in the middle, the place of the virtual insect body, remaining empty. During everyday use, this is the critical area for potential damage. In addition to other technical details, press reports highlighted the fact that a fingerprint sensor was attached to the side of the phone - right where the thumb usually rests when using a mobile device. Yet both this making-appear of pairs of related butterfly wings upon folding or hinged objects and the function of places preformatted to be accessed or touched by fingertips can be found much earlier in interlinked assemblages of cultural techniques, as the following essay shows. ${ }^{2}$

\section{Packages}

At some point, the three slipcases in the format of $16.7 \times 10.7 \times 2.9 \mathrm{~cm}$ (Fig. 1) covered with dark green patterned paper must have looked more or less identical. In the meantime, however, they have become easy to tell apart even if one disregards the inscriptions applied with black ink. The slipcase no. 1 has a discol-

\footnotetext{
1 Details had already been leaked shortly before; see https://www.indiatoday.in/technology/ news/story/samsung-galaxy-fold-foldable-phone-leaks-out-in-press-renders-ahead-of-unpackedevent-1460330-2019-02-20 (visited on February 22, 2019); illustrations can be found, for example, at https://www.nytimes.com/2019/02/20/technology/personaltech/samsung-galaxy-s10.html?action=clickodule=Discoverygtype=Homepage (visited on February 22, 2019).

2 Regarding the specific form of this making-appear of folding or hinged objects, see Helga Lutz, "Medien des Entbergens: Falt- und Klappoperationen in der altniederländischen Kunst des späten 14. und frühen 15. Jahrhunderts,” Archiv für Mediengeschichte 10 (2010): Renaissancen: 27-46, here 32.
}

Translated by Michael Thomas Taylor 


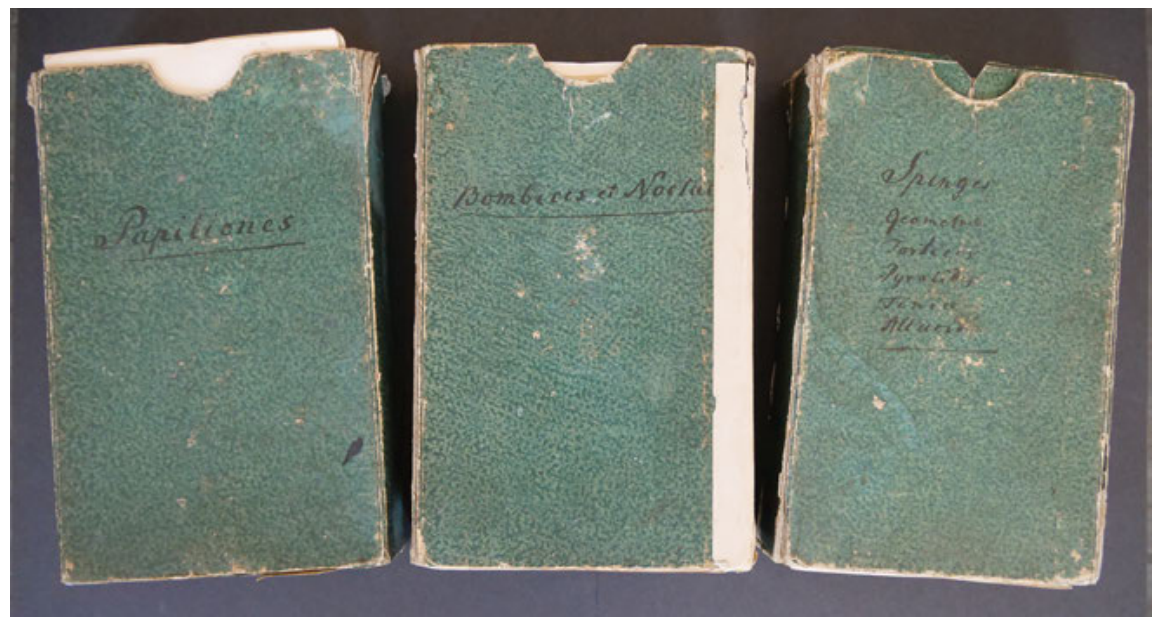

Fig. 1: Three labeled slipcases - in German, Schuber: (1) Papillones, (2) Bombices et Noctu[ae], (3) Spinges, Geometridae, Tortices, Pyralides, Tinides, Allucides (presumably around 1850, private collection).

oration in the upper right corner caused by moisture, which extends across the narrow right side and affects the entire left third of the back. On the lower right side of the front, a thick spot of ink rests like a black bird amid the foliage of the dark-green paper. The other two slipcases, one of which (no. 2) was repaired with adhesive tape, have lost their bottoms, exposing the lower edges to increased abrasion. Slipcase no. 3 is the only one that contains an inner case, made of colored paper; this inner case is visible at the upper edge, where a semicircular notch has been created to make it easier to pull out the contents.

The individual changes and losses refer, ex negativo, to the basic function of all slipcases: they are "protective containers" made by machine or (as in this case) manually by scratching, folding, and/or assembling, intended to protect the contents from damage caused by dust, moisture, impact, tearing, and climatic fluctuations. ${ }^{3}$ Yet from the perspective of linguistic history, the German word Schuber (sg./pl.) has multiple references. In the archival world, it can mean a bound or unbound heap or pile (the latter corresponding to the word Schober in the sense of "layered pile of grain"), ${ }^{4}$ but it can also denote a container or a cover

3 "Schuber," in Lexikon des gesamten Buchwesens, vol. 7, ed. Severin Corsten, Stephan Füssel, and Günther Pflug (Stuttgart: Hiersemann, 2007), 634.

4 Friedrich Kluge, “Schober,” in Etymologisches Wörterbuch der deutschen Sprache (Strassburg: K.J. Trübner, 1910), 411. 
for documents or bundles of files. ${ }^{5}$ The word points etymologically to practices of schieben, or pushing, whereas the English "slipcase," by contrast, more likely originates from the slipping/gliding of the contents it is meant to protect. Beyond these etymological and historical conditions, systematic implications arise from the cultural-technical practices that converge in the object Schuber: Schuber are operational assemblages that aim to stabilize what they hold and thereby, through their respective formats, realize dimensional templates.

But how do these three "slipcases" relate to what they hold as something capable of slipping out? Symbolically, the inscriptions on the front sides (which is what makes these sides the front to begin with) refer to contents from the order of butterflies or moths, the Lepidoptera (named thus because of their characteristic wing scales). The insertions are made available, in cultural-technical terms, through the semicircular notch I mentioned above, which is positioned at the top in the middle of the front and back sides of the Schober: paper restorers call it a Griffmulde or Greifausschnitt (a notch or cutout for grasping or gripping) or just an Eingriff (slit, intrusion). ${ }^{6}$ Their symmetrical attachment to the slipcase has an affordance function adapted to the physiology of the human hand, designed especially for the thumb and the index or middle finger, which are most adept at grasping the Schober of paper and pulling it out. ${ }^{7}$

\section{Unpacking}

At first glance, what slips out of the slipcase seems to be simply an assemblage of cultural techniques: a depiction of butterflies on sheets of slightly rough paper. In part, they have been given inscriptions in pencil or ink (in the case of the inscriptions in pencil, the genus is shown at the top left, the species name at the bottom

5 Heinrich Otto Meisner, Archivalienkunde vom 16. Jahrhundert bis 1918 (Göttingen: Vandenhoeck \& Ruprecht, 1969), 49.

6 Translator's note: this use of the word Eingriff is unusual. An Eingriff usually refers to "an (unjustified or unauthorized) intervention," a surgical operation, or the fly on a pair of pants (Duden); like Griffmulde and Greifauschnitt, it is based on the German word greifen, to grasp, grip, or grab. 7 See Richard Fox, Diamantis Panagiotopoulos, and Christina Tsouparopoulou, "Affordanz," contibution to SFB 933 "Materiale Textkulturen": https://www.degruyter.com/downloadpdf/ books/9783110371291/9783110371291.63/9783110371291.63.pdf (visited on February 22, 2019); the exhibition catalogue Das bewegte Buch, which assembles a wealth of materials into forms and formats of collecting, touches upon this arrangement of cultural techniques in passing in relation to Lavater's experiments with loose-leaf books; see Marbacher Magazin 150/151/152, ed. Heike Gfrereis (Deutsche Schillergesellschaft: 2015), 30, and related illustrations. 


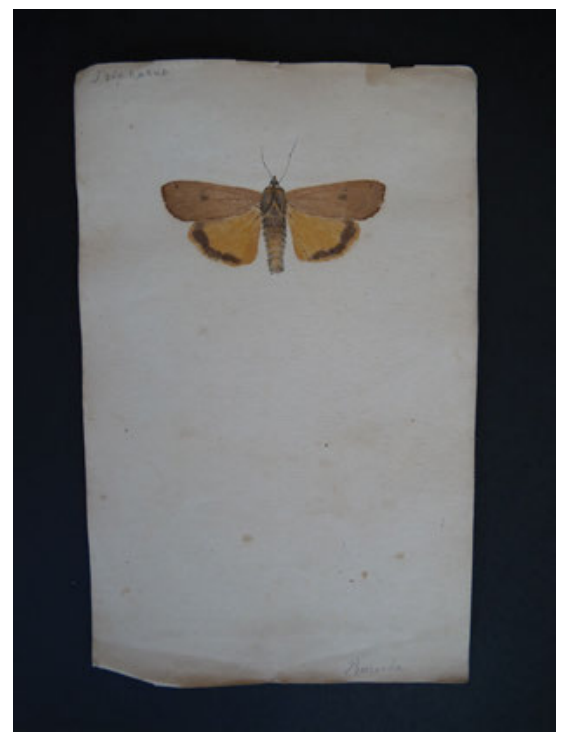

Fig. 2: Sheet 112 r from slipcase 2.

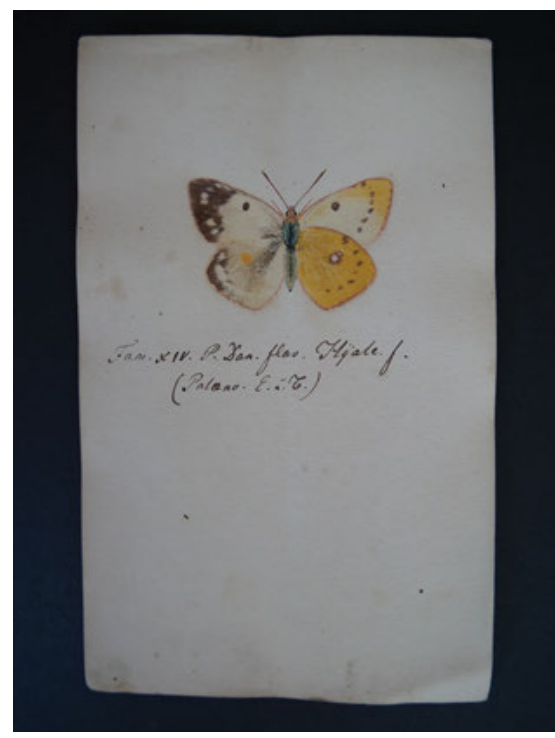

Fig. 3: Sheet $75 \mathrm{r}$ from slipcase 1.

right, Fig. 2, while the categorizations in ink are found beneath the illustrations, Fig. 3). Often the inscriptions are missing completely.

The flat, two-dimensional plainness of the arrangements is crossed by a (usually vertical) folding of the sheets, which runs exactly down the middle between the feelers and the wings of the butterflies. The two-dimensionality of the sheets, already eliminated by folding, finally disappears completely on the microlevel, revealed when the objects are placed under a microscope or stereomicroscope that shows the spatial structure of the scales as it actually exists, lying on the wings like roof tiles. The insect bodies lying between the wings, including the eyes and antennae, remain flat: they have indeed been painted by watercolor. On about one fifth of the sheets, these "artistic" additions are missing and only the wings are present. In these cases, specifically, the dried residue of a previously more or less liquid substance can be seen, left behind on the paper as a darkened area (Fig. 4).

The objects collected in the three slipcases were created using what is known as the Naturselbstdruckverfahren (nature self-printing or self-imprinting) as it was essentially developed - with earlier precursors - in the sixteenth and seventeenth centuries, to then be used throughout the eighteenth and nineteenth centuries, and as it is still being used today, in various modified forms, to document plants, animals, and other natural objects. Nevertheless, the practices denoted by this name (other names in German include Naturdruck, Physiotypie, and Autoplastik) 


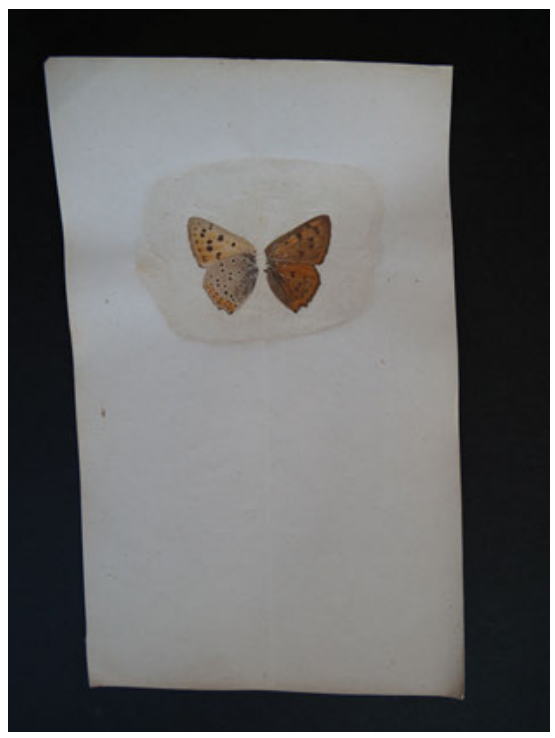

Fig. 4: Slipcase 1, sheet 31r (detail).

are quite diverse and the tools used to carry them out are quite varied. By far the majority of documented attempts concern self-imprints of plants, as we already see in early evidence from the thirteenth and fourteenth centuries. ${ }^{8}$ The case I am discussing here concerns a variant that, strangely enough, only plays a secondary role, if any, in more recent scholarly depictions of Naturselbstdruck, although it has sometimes also been described as the technique of Naturselbstdruck in the true and narrower sense, in which "natural objects or parts thereof are directly used to make an impression, as carriers of color," compared with the more

8 Previous work to be noted includes Peter Heilmann, "Über den Naturselbstdruck und seine Anwendung," in Die Sache selbst, ed. Silke Opitz and Gerhard Wiesenfeldt (Weimar: BauhausUniversitäts-Verlag, 2002), 100-110; Amin Geus, Natur im Druck: Eine Ausstellung zur Geschichte und Technik des Naturselbstdrucks (Marburg an der Lahn: Basilisken-Presse, 1995), especially the chapter by Armin Geus, "Natur im Druck: Geschichte und Technik des Naturselbstdrucks," 9-27; Gianenrico Bernasconi, "The Nature Self-Print," in Objects in Transition: An Exhibition at the Max Planck Institute for the History of Science, Berlin, August 16-September 2, 2007, catalogue to the exhibition ed. Gianenrico Bernasconi, Anna Maerker, and Susanne Pickert (Berlin: Max Planck Institute for the History of Science, 2007), 14-23; Lorraine Daston and Peter Galison, Objectivity (New York: Zone Books, 2010), 105-133; "Exkurs: Der Naturselbstdruck, “ in Die Buchkultur im 19. Jahrhundert, vol. 1, ed. Walter Wilkes, Frieder Schmidt, and Eva-Maria HanebuttBenz (Hamburg: Maximilian-Gesellschaft, 2016), 235-242; Friedrich Weltzien, Fleck - Das Bild der Selbsttätigkeit: Justinus Kerner und die Klecksografie als experimentelle Bildpraxis zwischen Ästhetik und Naturwissenschaft (Göttingen: Wallstein, 2011), 303-309; and Simon Weber-Unger, Naturselbstdrucke: Dem Originale identisch gleich (Vienna: Album, 2014). 
general technique of "nature printing." 9 For this reason, with this technique it is also impossible to make several, in principle nearly identical, prints from one source element, as happens in the case of plants prepared with printing ink or the use of various lead or copper form transfer media on which "natural" objects can leave a trace. ${ }^{10}$ Descriptions of the technology can be found above all where the objects involved call for it, for example, in a 2016 contribution to a collection ensemble from the holdings of the Letter-Stiftung:

In contrast to the more common natural self-printing of objects such as leaves or feathers, which are inked and then printed, the natural self-printing of butterfly wings is based solely on the transfer of the colored wing scales onto paper that has been previously prepared with a thin, adhesive layer. The exoskeleton and veins of the wing can then be carefully removed while the scales remain stuck to the surface. ${ }^{11}$

A relevant historical source from 1889 describing the specific process for the production of natural self-prints with butterflies is also mentioned here. In that source, one reads:

Dr. Vanhöffen presented a collection of butterfly prints and talked about the process of preserving butterflies as a natural self-print. One takes a small sheet of white paper folded in the middle and coats one side of it in a thin layer of highly viscous white gum arabic. Then, one folds the paper together, spreading the gum onto the other half to form an equally large area and rubs the gum very thinly and evenly on both sides. The wings of one side of a butterfly are then placed with a pincette just as the butterfly usually holds them in flight, whereupon both halves of the paper are folded up again and glued together by gentle pressure. Gradually, the wings are pressed together a little harder until the gum is almost dry and then the paper is unfolded. This succeeds easily, since the gum dries earlier where the wings form a dry intermediate layer than it does in the surrounding area, where two damp spots are touching. After removing the wing exoskeleton, one washes off the excess adhesive with a brush and water, dries the sheet between tissue paper, and completes the print by painting the butterfly body with watercolors. This results in a natural self-print that shows the upper side of the butterfly wings on the right and the underside on the left, or vice versa. If the aim is to make an impression of the top of the whole butterfly, however, one must place the four

9 Geus, Natur im Druck, 24.

10 Examples of this can be found in the publications listed above in note 8.

11 Collection cabinet with 510 natural prints of butterfly wing pairs, held by the Letter-Stiftung, new acquisitions, available at http://www.letter-stiftung.de/index.php/leser-83/items/schmetterlingskaestchen.html (visited on February 15, 2019). I owe my finding of this trace to Andrea Hübener (Braunschweig); I would also like to thank Viola Richter from the Museum für Naturkunde, Leibniz-Institut für Evolutions- und Biodiversitätsforschung (Berlin) for numerous hints and insights. 
wings in the correct position on a sheet treated with gum and cover it with another piece of gum-coated paper. ${ }^{12}$

It remains noteworthy that even if the practice described here represents, in a certain sense, an opposite procedure to the other processes described as "natural self-printing" (in one case, the material is colored; in the other, it is preserved with all its colors and made to adhere by the transparent gum arabic), it is nevertheless usually grouped together with them in historical and systematic terms. The use of the transmission medium is simply understood as another variant ${ }^{13}$ of accepting the affordance (or "invitation") of nature to be represented. But it is precisely the relationship between an "invitation" and a reply in terms of cultural techniques that differs significantly in the case of butterflies and their transformation into natural self-print ensembles, compared to what happens in the case of other techniques. The difference lies not only in the additional spatial dimension that is gained but also in the interconnected cultural-technical, abstract spatial prerequisites and consequences of the associated operations.

This concerns, first of all, the coupling of the operations: the simple folding of the paper generally couples each pair of the four wings that every butterfly has, making them into a double: the sheet thereby follows the movement the butterfly employs to fly, in which all four wings are moved simultaneously - perhaps giving the impression that the insect has only two wings. The coupling of cultural techniques is thus, in a certain sense, preformatted as a natural technology. At the same time, however, the printing process leads to what we might call a distortion of the natural format and thus also of the reality effect linked to it, which makes us believe that we see the shape of a butterfly (even without the addition of a body - as was also the case with the folding mobile phone). However, there are no such things as butterflies with wings whose upper and lower sides are simultaneously visible, and because both pairs of wings have been removed from one original pair of wings, they cannot be transformed into a natural state, as it were, by operations in two or three-dimensional space. The procedure of removing both pairs of wings of a butterfly at the same time that was mentioned in the last sentence of the description cited above avoids this disfiguration but only by abandoning the integrity of clear scientific illustration: the front and back sides

12 Meeting of May 2, 1889, in Schriften der Physikalisch-Ökonomischen Gesellschaft zu Königsberg 30 (1889): 24-25, here 24 (accessible online at https://www.biodiversitylibrary.org/ item/51236\#page/110/mode/2up, visited on February 15, 2019); in the description provided by the Letter-Stiftung (see above, note 11) the speaker is listed as Ernst Vanhöffen (1858-1918).

13 Weltzien, for example, writes of a "rubber-like substance" that made it possible to refine the previous technology; Weltzien, Fleck - Das Bild der Selbsttätigkeit, 308. 
of each pair of wings (in the first method) can represent the color and shape patterns of the whole wing apparatus, whereas the view of only the front sides of four wings (in the second method) can never represent the whole. In both cases, however, the transfer of the scales to the paper is accompanied by a further shift: the top side of the scales that are pressed onto and adhere to the paper always faces the paper base, so that the viewer of the finished preparation can only perceive the backs of the scales of the upper and lower wings (which normally remain invisible inside the wing). This usually goes unnoticed given that butterfly scales are colored on all sides. Only the blue color, Vanhöffen notes, poses "some difficulty," especially in the case of the blue male butterflies of the genus Lycaena: these butterflies have shorter brown scales under the blue scales, which cover the blue scales in a natural self-print. The impression of the male therefore shows the simple brown color of the female, which lacks the blue scales. ${ }^{14}$

The butterflies represented in natural self-printing by means of only one pair of wings are thus assemblages that undergo recto/verso transpositions on several levels. First, they adapt to the ground on which they are held (namely, the sheet of paper) in the format of folding; second, they separate themselves from the ground (in that the recto and verso dyad of a double wing appears here juxtaposed on the recto of the paper); and third, they present themselves with a view of the scales on the back that is hidden in nature.

As a transition area between the two sides of the folded geometric construction, the free space between the pairs of wings at first remains ontographically uncoded. If bodies are inserted by means of watercolor, the structure becomes something like an artistic trompe-l'oeil, although, for the reasons given above, the effect goes beyond the Euclidean scheme of reference that a first glance might suggest. ${ }^{15}$ If these bodies are lacking, however, then the constructedness of the arrangement comes to the fore, often accentuated by the traces of gum arabic left behind in such self-prints as the medium enabling this operational disfiguration. Yet in the case of this collection, as a rule only those specimens with painted bodies were deemed worthy of being labeled, whereas the wings that remain by themselves are almost always unlabeled. The trace of the pencil

14 Meeting of May 2, 1889, in Schriften der Physikalisch-Ökonomischen Gesellschaft zu Königsberg, 30 (1889): 25.

15 Indeed, the arrangement could be understood as a superposition of different spaces that are "enacted" in the first place by the underlying operational chains (according to Helga Lutz and Bernhard Siegert, with reference to John Law, in an essay on collapsible and foldable pictorial objects); see Lutz and Siegert, "In der Mixed Zone: Klapp- und faltbare Bildobjekte als Operatoren hybrider Realitäten,” in Klappeffekte: Faltbare Bildträger in der Vormoderne, ed. David Ganz and Marius Rimmele (Berlin: Dietrich Reimer, 2016), 109-139, here 112. 
thus becomes the countersignature of a union of the hybrid thing-space with the drawing space; since the view of the front and back sides of the wings would be quite sufficient to determine the species, here the hybrid body is to be understood as the symbolic medium that, at the interface between the material and the conceptual dimensions of the object, activates the space of meaning in the first place. ${ }^{16}$

\section{Affiliations}

The butterflies are redimensioned as epistemic objects by nature's self-printing, that is, they are given a manageable and transportable form ${ }^{17}$ while remaining comparatively fragile, from a conservationist point of view: they rely on stabilizing media such as slipcases, cassettes and - on another level of nesting protective cabinets, ${ }^{18}$ while indirect natural self-prints might also end up in locations more exposed to physical wear and tear, such as book pages. The article from Königsberg further highlights corresponding advantages and possible applications of self-printing in areas of science, pedagogy, and art. $^{19}$ The referential chains of cultural technologies into which the ensemble of the collection is integrated, however, extend beyond such pragmatic classifications and similarly also connect to many pragmatic contexts. ${ }^{20}$ For the subsequent history of natural self-printing in the nineteenth and twentieth centuries, the criminological practices of fingerprinting and the history of early photography are the best-known affiliations. ${ }^{21}$ As single specimens and in the special form of the butterfly natural

16 See Lutz and Siegert, "In der Mixed Zone," 138-139; and Hans-Jörg Rheinberger, "Zettelwirtschaft, " in Schreiben als Kulturtechnik, ed. Sandro Zanetti (Berlin: Suhrkamp, 2012), 441-452, here 442.

17 See Rheinberger, "Zettelwirtschaft," 443, with reference to Bruno Latour's text, which has by now acquired the status of a classic: Bruno Latour, "Visualisation and Cognition: Drawing Things Together," Knowledge and Society: Studies in the Sociology of Culture and Present 6 (1986), 1-40.

18 See Anke te Heesen and Anette Michels (eds.), Auf/zu: Der Schrank in den Wissenschaften, exhibition catalogue (Berlin: De Gruyter, 2007).

19 Meeting of May 2, 1889, in Schriften der Physikalisch-Ökonomischen Gesellschaft zu Königsberg, 30 (1889): 25.

20 Here, my concept of the "referential chain" follows Latour's concept in a generalized form as explicated in Bruno Latour, "Selbstportrait als Philosoph," http://www.bruno-latour.fr/sites/ default/files/downloads/114-UNSELD-PREIS-DE.pdf (visited February 28, 2019).

21 On the systematic connection between natural self-prints and dactylograms, see Geus, Natur im Druck, 20 and 27; on natural self-prints and photography, see Rolf H. Krauss, "Fotografie und 
self-print, they are, in accordance with the historical circumstances of the collection, only occasionally involved in such affiliations. For example, only those sheets of the collection are exposed to fingerprints that belong to the collective of holdings that were handed down in slipcases without a protective case (slipcases 1 and 2).

Overall, however, many connections remain to be clarified. It is true that the nearly 350 specimens in the collection almost seem to be objects directly demonstrating the method that Ernst Vanhöffen presented to the physical-economic society in Königsberg and then explained in its journal. Since the origin of the present collection itself is unknown and no relevant notes can be identified in the three convolutes, one can only speculate as to whether there was a real historical and local connection to the surroundings of Ernst Vanhöffen (1858-1918). Incidentally, just a few weeks after his lecture in Königsberg in July 1889, Vanhöffen set out to take part in the first expedition to the Atlantic dedicated specifically to the exploration of plankton, and in later years he traveled nearly the entire globe on further expeditions.

Conversely, the individual butterflies whose wings were added to the collection - surrendering those specific body parts while also revealing their existence as a species - came from relatively distant regions and biotopes, but they are essentially European, not exotic, species. Just as the gum arabic forms a kind of halo around each individual preparation, the butterflies can be embedded as a collective in a kind of virtual cloud of their origin. As Merck's Warenlexikon of 1884 emphasizes, the gum arabic itself ultimately came not from Arabia but from Africa and would, according to the editors, therefore be "better called African gum, because Africa is the true home of the thorny acacias or mimosas that exude the material.".22

Yet it is not so much the origins that matter as the routes these techniques traveled. By the early nineteenth century, the technique of natural self-printing had probably already spread to Japan, where it prominently remained in use. ${ }^{23}$ It would need to be clarified whether prints or natural self-printed preparations were also produced in Korea. The same holds for a possible connection of the latest technological designs of mobile devices to the technology of natural self-printing of butterfly wings, which is comparatively marginal in the context of naturally reproductive processes. In the future, if the hopes of the manufac-

Auers Naturselbstdruck: Kontaktbilder als Medien einer mechanischen Objektivität,” Fotogeschichte 121 (2011): 13-24.

22 Art. "gumarabicum,"in Merck's Warenlexikon(1884), http://www.retrobibliothek.de/retrobib/ seite.html?id=45534\#Gummi arabicum (visited on February 15, 2019).

23 Peter Heilmann, "Über den Naturselbstdruck und seine Anwendung," 107-108. 
turers are fulfilled, their optically "adjusted" shape enriched with a brilliant blue will form a new branch in the family tree of hybrid operational chains, with the natural self-printing process of the fingerprint having been transferred into digital coding. 
